\title{
The Open-Ended Problem Based Mathematics Learning to Increase Students' Creativity on Fraction for Third Grade Elementary School
}

\author{
Nur Indah \\ Primary Education Studies Program, Universitas Negeri Surabaya, Indonesia \\ nurindah16070855071@mhs.unesa.ac.id \\ Mega Teguh Budiarto, Agung Lukito \\ Mathematics Departments, Universitas Negeri Surabaya, Indonesia
}

\begin{abstract}
This study aims at developing an open-ended problem based mathematics learning to enhance students' creativity. Plomp model was used to develop the instructional materials for fraction unit at grade 3. The subjects consisted of third grade students. The data was collected by observation, interview, test, dan questionnaire. The data were analyzed based on the validity, practically, and effectiveness of open-ended problem based mathematic learning. To know that the learning does enhance the students' creativity the research implemented a quasi-experiment research. The results show that the instructional materials meet the criteria validity, practically, and effectiveness and students' creativity of the experiment group outperform the control group. In accordance with the research results, so that, learning based on open-ended solving problems can be used as an effort to improve student's creativity.
\end{abstract}

Keywords-Creativity: Open-Ended Problem: Problem Solving.

\section{INTRODUCTION}

Creativity is one of important competencies that must be developed through education. Piirto stated that at this time, there is skill or expertise which needed in the 21 st century, and that skill includes creativity skills [9]. Akgul and Kahveci also stated that creativity is an invaluable skill for the new century [1]. From this view, the goals and demands of national education, it is clear that the creativity aspect is one of the objectives that must be considered in educational activities. Creativity is the ability to produce any composition, product, or idea that is essentially new and never been used before [4]. Silver suggested three components to assess the creativity of children and adults: fluency, flexibility and novelty [11]. Fluency refers to the number of answer ideas that students have to answer, flexibility refers to how many ideas students use to share images, and novelty refers to the idea of answers and ideas of the way that the students give comes from their own ideas.

The conceptual definition of creativity involves elements that include novelty, eligibility, and the task must be heuristic for the individual rather than the algorithmic whereas the task must be open (open-ended) [12]. Accordingly, in order to produce a creative product, the tasks assigned to the student must be open-ended with no single solution. This claim is supported by the statement of Walle that a good question has many ways of completion [13]. The results of Kwon, et al. study on divergent thinking in mathematics through openended learning showed that the posttest grade average score using open-ended learning is much higher than non-openended classes [6]. This suggests that open-ended learning has an influence in improving divergent thinking skills in mathematical creativity.

Mathematical learning through open-ended problem solving provides an opportunity for students to use their ability to dig information and connect with relevant concepts and to solve problems in their own way. So students will indirectly perform creative thinking by finding a new way or answer correctly. This process will challenge students when solving problems in multiple ways based on their abilities.

The success of the learning process by the classroom teachers requires a set of sources. A collection of sources is a learning tool. Learning tool is a collection of resources that enable teachers and students to do learning activities. In this research, the development of learning tools was done based on open-ended problem solving which includes lesson plan (LP), student work sheet (WS), test result (TR), and Creativity Test on third grade elementary school with fraction material aimed to improve student creativity. Traditional programs for elementary schools usually delivered limited explanations about fractions which mostly discussed in third and / or fourth grades [13]. Therefore, the selection of materials aims to get students a clearer understanding and practice the ability to think creatively towards fractions.

Nieveen explains that a learning tool was said to be good if the tool were valid, practical, and effective [2]. The tool was said to be valid, if the tool compiled according to the subject of the appropriate discipline (content validity) and all components in the tool were connected to each other consistently (construct validity). The tool was said to be practical if the implementation of learning is categorized good and student activities in the effective category. The effectiveness of the tool is assessed from the student's positive responses and the completeness of student learning outcomes classically. This research objective was to produce learning tools based on open-ended problem solving to improve third grade elementary school student creativity. 


\section{METHODS}

This development research produced an instructional tool based on open-ended problem solving on third grade elementary school fraction material. The development model used in this research was the Plomp model [10]. This method consisted of: 1) Preliminary research, short description of activities is review of the literature and of (passed and/or present) projects addressing questions similar to the ones in this study. This results in (guidelines for) a framework and first blueprint for the intervention; 2) Prototyping stage, short description of activities is development of a sequence of prototypes that will be tried out and revised on the basis of formative evaluations. Early prototypes can be just paper-based for which the formative evaluation takes place via expert judgments; and 3) Assessment phase, short description of activities is evaluated whether target users can work with intervention (practicality) and are willing to apply it in their teaching (relevance \& sustainability). Also whether the intervention is effective [10].

The components of the intervention should be based on state-of-the-art of knowledge (content validity) and all components should be consistently linked to each other (construct validity). If the intervention meets these requirements, it is considered to be valid. Another characteristic of high-quality interventions is that end-users (for instance the teachers and learners) consider the intervention to be usable and that it is easy for them to use the materials in a way that is largely compatible with the developers' intentions. If these conditions are met, we call these interventions practical. A third characteristic of high quality interventions is that they result in the desired outcomes, i.e. that the intervention is effective [10]. The data obtained were analysed to determine the validity, practicality and effectiveness of the tool and the effectiveness of the learning. Analysis of student's creativity data was done by using ANCOVA.

\section{RESULTS}

\section{A. The Description of Learning Tool Development}

The development of learning tools includes lesson plan (LP), worksheet (WS), learning result test (TR), and Creativity Tests called Prototype I. Besides, research instruments were also compiled which include questionnaire validation sheets, observation sheets for learning implementation, student activity observation sheets, student response questionnaires.

\section{Lesson Plan}

Problem solving based learning was integrated in each learning that refers to the learning step. In the debriefing step / presenting open-ended problems students will be introduced and explore ideas in finding answers and correct ways more than once. Open-ended problems were used in learning and applied in accordance with the learning steps listed.

\section{Worksheet}

In the introduction part of worksheet mentions about basic competencies, goals, instructions and group names. Furthermore, there was an introduction in the form of motivation or information and activities. Next, an open-ended problem was presented which refers to students' daily lives about fractions according to their indicators. An interesting worksheet design was expected to motivate students in learning fractions.

\section{Test Result}

Learning result test was developed that aim to measure individual's completeness and its classical completeness as students' understanding determinants after learning was completed on fraction material. Learning result test was arranged in the form of 6 questions.

\section{Creativity Test}

The creativity test was developed which aim to measure student's creativity after received treatment on fractional material. The Creativity Test questions was in the form of open-ended problems that given at the pretest and posttest. The question of Creativity Test consists of two items in the form of a description.

\section{B. Learning Tool Validity}

The tool validity results from the assessment of validator I, II, and III toward lesson plan (LP), work sheet(WS), test result (TR), and Creativity Test. It can be stated valid because all validator provided an assessment with a minimum score of 3 for each aspect. For constructs validity of test result (THB) was obtained valid results, reliable, and sensitive.

TABLE I: THE COEFFICIENT OF VALIDITY OF LEARNING OUTCOMES

\begin{tabular}{|c|c|c|}
\hline Number & Coefficient of Validity & Category \\
\hline $\mathbf{1}$ & 0,62 & Medium \\
\hline $\mathbf{2}$ & 0,84 & Very High \\
\hline $\mathbf{3}$ & 0,82 & Very High \\
\hline $\mathbf{4}$ & 0,88 & Very High \\
\hline $\mathbf{5}$ & 0,76 & High \\
\hline $\mathbf{6}$ & 0,83 & Very High \\
\hline
\end{tabular}

Based on the results in Table 1, each test item was meets valid criteria. The results of the test reliability coefficient were 0.87 with a variance of 8.38 and a total variance of 30.46 . This showed that the Validity of the Learning Result Test developed is very high.

The results of sensitivity calculation showed that the category of each sensitivity test item on the learning got scores $>0.3$. The sensitivity index of a question item shows the ability of test items to distinguish between students before receiving learning and after receiving learning.

\section{TABLE II: SENSITIVITY OF LEARNING OUTCOME TEST ITEM}

\begin{tabular}{|c|c|l|}
\hline Task Number & Sensitivity of Test Item & Category \\
\hline 1 & 0,57 & Sensitive \\
\hline 2 & 0,63 & Sensitive \\
\hline 3 & 0,57 & Sensitive \\
\hline 4 & 0,71 & Sensitive \\
\hline 5 & 0,44 & Sensitive \\
\hline 6 & 0,65 & Sensitive \\
\hline
\end{tabular}




\section{Practicality of Learning Tools}

Implementation of learning tools during trial can be summed up to be used properly. The results of observation showed that the score of implementation for each meeting gets a minimum score of 3 for each aspect.

On the first meeting, observation result to student activity was appropriated to expected activity namely $90.00 \%$, the second meeting was $88.57 \%$, and at the third meeting was $90.00 \%$. The percentage of student activity from the three meetings in the experiment class corresponding to the expected activity wasmore than $85 \%$, so it can be concluded that the student activity was good during open-ended problemsolving learning.

\section{The Effectiveness of Learning Tools}

Student response to learning was in the positive category where as the number of students who gave positive response > $70 \%$. The completion of classical learning in the experiment class was achieved where the analysis of test result data on the experiment class obtained 19 students $(82.6 \%)$ has achieved learning mastery.

\section{E. Learning Effectiveness Based on Open-Ended Problem Solving}

Learning based on open-ended problem-solving was effective considered from tool implementation because the observations show that the value of implementation for each meeting scores at least 3 for each aspect.

At the first meeting the observed student activity corresponding to the expected activity was $87.14 \%$, the second meeting was $88.57 \%$, and third meeting was $91.43 \%$. Of the three meetings, the percentage of observed student activity that corresponds to the expected activity wasmore than $85 \%$, so it can be concluded that student activity is good during open-ended problem-solving learning.

Student's responses to learning in the experimental class are categorized positively because they get the score with strong minimum category, so that the effective learning is viewed from the student's response to the learning.

The result of the test result of the students' learning result in the experimental class was obtained by the students who got the minimum score of 65 that is 21 from 25 students $(84 \%)$. Student learning completeness in class in experimental class is achieved. So the learning-based problem of open-ended problem solving is effectively viewed from the students' learning mastery.

\section{F. Creativity Result}

\section{Creativity of Experiment Class Students}

The researcher took a sample of the creativity test answers with the highest creativity scores in the experimental class in Figure 1.

From experimental class student's answers in the learning based on open-ended problem solving can be explained in the Table 3.

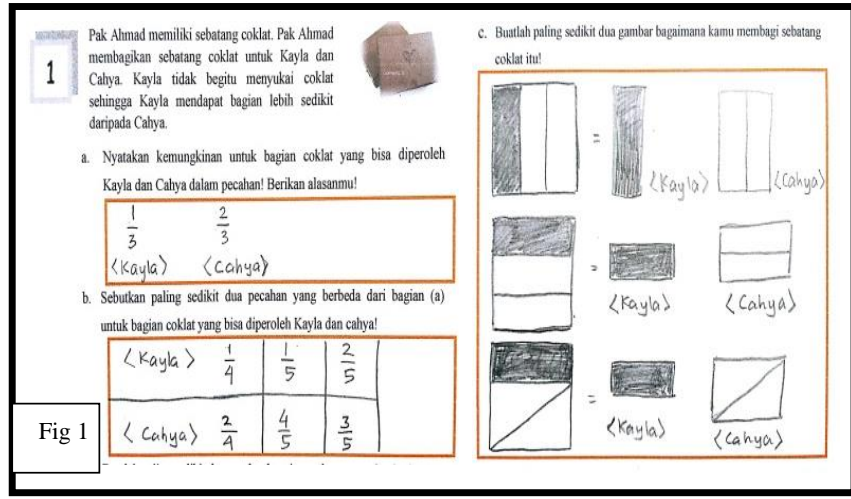

Figure 1. Answer to creativity test for experimental class

TABLE III: DESCRIOTION OF THE INDICATOR CREATIVITY BASED ON THE ANSWER OF THE EXPERIMENTAL CLASS

\begin{tabular}{|l|l|}
\hline \multicolumn{1}{|c|}{ Indicator } & \multicolumn{1}{c|}{ Description } \\
\hline Fluency & Give 3 answers with 2 answer ideas \\
\hline Flexibility & $\begin{array}{l}\text { Using chocolate cake cutting method with 3 ways and } \\
\text { 2 way ideas }\end{array}$ \\
\hline Novelty & Do not imitate others and use methods by combining \\
\hline
\end{tabular}

\section{Control Class Student's Creativity}

The researcher also took a sample of the creativity test answers with the highest creativity scores in the control class in Figure 2.

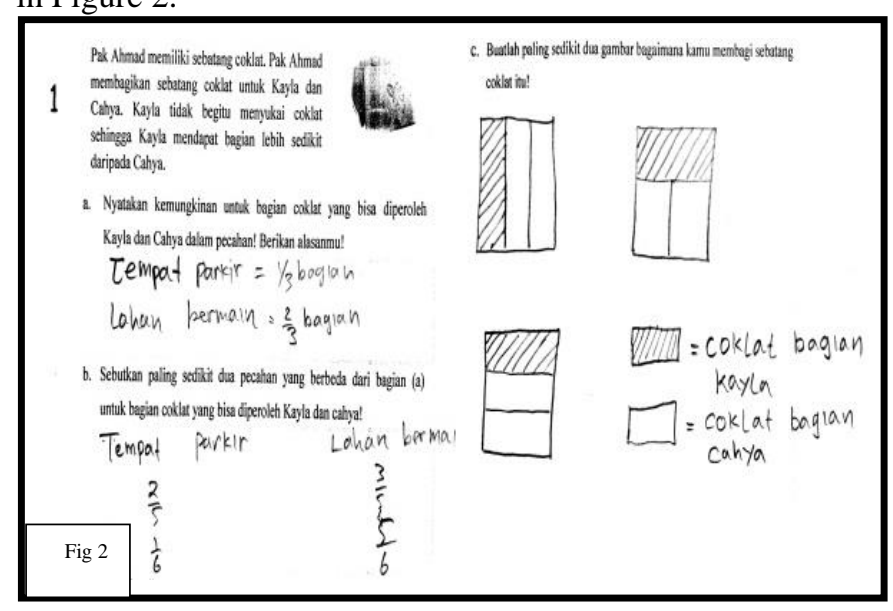

Figure 2. Answer to creativity test for control class

From control class student's answers in the conventional learning can be explained in the Table 4.

TABLE IV: DESCRIOTION OF THE INDICATOR CREATIVITY BASED ON THE ANSWER OF THE CONTROL CLASS

\begin{tabular}{|c|c|}
\hline Indicator & Description \\
\hline Fluency & Give 2 answers with 2 answer ideas \\
\hline Flexibility & $\begin{array}{c}\text { Using chocolate cake cutting method with 3 ways and 1 } \\
\text { way ideas }\end{array}$ \\
\hline Novelty & Do not imitate others but this method has been used before \\
\hline
\end{tabular}

\section{Anacova Result}

According to the results of creativity in the sample in the experimental class and control class showed that students in 
the experimental class with open-ended problem solving based learning were able to provide ideas of answers and method (ways) ideas than the students in the control class with conventional learning. Student with problem-solving learning was also able to do a combination of methods that have never been used before.

Furthermore, inferential statistical analysis was performed on the students' creativity scores in the experimental class and control class (Anacova) which aims to determine student's creativity improvement between the experimental class and the control class with several steps including normality test, regression model, independence test, linearity test, and equality test. The results obtained from each Anacova steps can be concluded that the creativity of students that taught by learning based on solving open-ended problems was better than student's creativity with conventional learning.

\section{DISCUSSION}

This research was produced good learning tools based on open-ended problem solving by meet valid, practical, and effective criteria. The effectiveness of problem-solving-based learning was effective in terms of the implementation of learning, student's activities, student's positive responses, and mastery of student learning outcomes of the experimental class.

The results of research Kwon about divergent thinking in mathematics through open-ended learning showed that the posttest class mean score using open-ended learning was much higher than class that did not use open-ended learning. This showed that open-ended learning has an influence in fostering divergent thinking skills in mathematical creativity [6].

Problem solving develops creativity and improves mathematical concepts [3]. The way to improve a mathematical creative thinking ability can use an open problem or open-ended problem in nature. This problem was designed so that there may be more than one correct answer option or there may be more than one option to get answers, so it can challenge students at various levels of cognitive development. Problems used can be made from student's experience or by modifying questions [8].

\section{CONCLUSION}

Using a modified Plomp model [10], an open-ended problem-solving learning tool has been developed in the form of lesson plan (LP), work sheet(WS), test result (TR), and Creativity Tests for on fraction materialthat meet the criteria. This wasshowed by: 1) The resulting tool is valid; 2) The ability of teachers to manage good learning; 3) Student activity is effective; 4) Student's response to positive learning; and 5) learning completeness was achieved classically. Based on the results of descriptive analysis, open-ended problem-solving learning is effective for teaching fractional material. It was based on 1) learning completeness was achieved by classical, i.e. $84 \%$; 2) The good ability of teachers managed learning for each meeting; 3) Student's activity was in the effective category; and 4) The students responded positive learning. Based on the results of inferential statistical analysis concluded that the creativity of students who follow the learning-based open-ended problem solving was better than the creativity of students who follow the conventional learning for third grade fraction material in Tenaru elementary school. So, it can be concluded that open-ended problem-solving learning on fraction material with valid, practical, and effective tools can improve student's creativity in third grade of elementary school.

\section{REFERENCES}

[1] S. Akgul and N. G. Kahveci, "A Study on the Development of a Mathematics Creativity Scale", Eurasian Journal of Educational Research, vol. 62, pp 57-76, 2016.

[2] J. V. D. Akker, et. al., "Design Approaches and Tools in Education and Training", 1999.

[3] M. Ayllón, I. Gómez, and C. J. Ballesta, "Mathematical Thinking and Creativity Through Mathematical Problem Posing and Solving", Propósitos Representaciones, vol. 4(1), pp. 169-218, 2016.

[4] E. Hurlock, Psikologi Perkembangan. Jakarta: Gramedia Pustaka, 2004.

[5] S. G. Isaksen, "Toward a Model for The Facilitation of Creative Problem Solving", Journal of Creative Behaviour, vol. 17, pp 18-30, 1983.

[6] Kwon et. al., "Cultivating Divergent Thinking in Mathematics Through an Open-Ended Approach", Asia Pacific Education Review, vol. 7, pp 51-61, 2006.

[7] T. Lowrie, "Designing a Framework from Problem Posing: Young Children Generating Open Ended Task", Contemporary Issues in Childhood, vol. 3(3), 2002.

[8] L. Munroe, “The Open-Ended Approach Framework”, European Journal of Educational Research, vol. 4(3), pp. 97-104, 2015.

[9] J. Piirto, "Creativity For $21^{\text {st }}$ Century Skills. Rotterdam: Sense Publishers, 2011.

[10] T. Plomp \& N. Nieveen, An Introduction to Educational Design Research, (Online), (Retrieved from www.slo.nl/organisatie/international/publications), 2010.

[11] E. A. Silver, "Fostering Creativity Through Instruction Rich in Mathematical Problem Solving and Thinking in Problem Posing", Electronic Edition ISSN Journal 1615-679X, vol. 29(3), 1997.

[12] T. Y. E. Siswono, Model Pembelajaran Matematika Berbasis Pengajuan dan Pemecahan Masalah untuk Meningkatkan Kemampuan Berpikir Kreatif. Surabaya: Unesa University Press, 2017.

[13] J. A. V. D. Walle, Matematika Sekolah Dasar dan Menengah Translator: Suyono. Jakarta: Erlangga, 2006 . 